\title{
THE TIME-SPACES OF CAPITALISM. SUZANNE DE BRUNHOFF AND MONETARY THOUGHT AFTER MARX
}

\author{
BY LAURENT BARONIAN*
}

\begin{abstract}
The paper is dedicated to Suzanne de Brunhoff's monetary thought and shows how her analysis of very concrete monetary and financial problems of her time led her to develop the most innovative contributions to Marxist theory of money since classical Marxism. Concepts such as noncontemporaneity of capitalism with itself, pseudo-social validation, conflict centralization or State management of money and labor power reflect her profound analysis of the ways capitalism generates very particular relationships to space and time. It is by looking at this spatio-temporal dimension of Brunhoff's concepts that this paper aims to reveal the novelty, power and fruitfulness of her monetary analysis. The first part of the paper seeks to define the meaning of the notion of general equivalent extracting from her reading of Marx's Capital, before situating her approach in relation to Institutionalist theories of money. The second turns to Brunhoff's analysis of the particular time-spaces of capitalism.

* CEPN, Université Sorbonne Paris Nord
\end{abstract}

This "preprint" is the peer-reviewed and accepted typescript of an article that is forthcoming in revised form, after minor editorial changes, in the Journal of the History of Economic Thought (ISSN: 1053-8372), issue TBA. Copyright to the journal's articles is held by the History of Economics Society (HES), whose exclusive licensee and publisher for the journal is Cambridge University Press (https://www.cambridge.org/core/journals/journal-of-thehistory-of-economic-thought ). This preprint may be used only for private research and study and is not to be distributed further.

The preprint may be cited as follows:

Baronian, Laurent. The Time-Spaces of Capitalism: Suzanne De Brunhoff and Monetary Thought After Marx. Journal of the History of Economic Thought (forthcoming). Preprint at SocArXiv, osf.io/preprints/socarxiv 


\section{INTRODUCTION}

Since Rudolf Hilferding ([1910] 2003), monetary theorists have been rare in Marxian economy. ${ }^{1}$ But what makes Suzanne de Brunhoff's work one of the most innovative contributions to monetary thought since classical Marxism is her concern with the practice of her time, and specifically financial and monetary practices after the establishment of the Breton Woods system and subsequent generalization of unconvertible fiat money. But what makes her thought truly singular and original is perhaps her specific way of addressing the questions raised by this new regime. Concerning the practices she examines, she merely asks: how does the law of value function in a monetary regime where commodity money has disappeared? How is the general equivalent reproduced, and what is the meaning of this notion in a developed credit system where private bank money and central bank money, scriptural money and fiduciary money coexist without one prevailing over the other since they are all created ex nihilo? How do we reconcile the idea of a monetary constraint imposed on everyone with the notion of monetary policy, which suggests that State institutions ensure full control over the supply of money, the value of money, etc.? Or, looking at State institutions: what is the mode of State intervention at a given stage of capitalism? And consequently, what can be inferred about the role and place of the State in capitalist society? What makes it a truly unique entity? These lines of inquiry are clearly far removed from questions regarding the essence of money, the origin and effects of market alienation (Reichelt, 2007), the theoretical status of the first section of Capital (Postone, 1993), or approaches to the State that presuppose its existence as a wholly constituted entity, whether to define its nature and functions, or to question the meaning of the relationship between its relative autonomy and "economic determination in the last resort" (Althusser, 2005).

Looking at the development of her work, it is remarkable that her initial investigation of a problem typically leads her to tackle new problems, which gradually broaden the scope of her analysis and

\footnotetext{
${ }^{1}$ For a survey on the current debate on Marxist theory of money, see Moseley (2005) and Lapavitsas (2017).
} 
reflection. Thus, from the question of the supply of money she proceeds to economic policy; then, from economic policy to the State; and finally, from the State to financial globalization. Across these various lines of inquiry, the common thread that brings unity to the whole can be found in the seemingly innocuous notion of general equivalent, insofar as it expresses the monetary constraint inherent in any market economy while simultaneously capturing all the contradictions that run through capitalism as a mode of production.

Suzanne de Brunhoff's analysis of these very concrete problems led her to develop a series of concepts, including: the non-contemporaneity of capitalism with itself (Brunhoff, 1976c), the concept of pseudo-social validation (Brunhoff, 1979), or the concept of conflict centralization (Brunhoff, 1986), which she developed long after her early analysis of the supply of money (Brunhoff, 1971) in order to account for the new role of the central bank in an unconvertible fiat money regime. Lastly, she captured the nature of State practices through the concepts of State management of money and labor power, two interrelated notions around which all these practices are organized. Moreover, the concepts of money and labor power management lay the foundations for a truly materialist theory of the State and State ideology (Brunhoff, 1976d), i.e. a theory that differs from traditional Marxist approaches of the State as an administrative apparatus of bourgeois affairs or a legal superstructure, as well as from the conceptions of Althusser (1971) (the State as an ideological apparatus), Pierre Bourdieu (1994) (the State as a meta-field) and Michel Foucault (2008) (the State as biopolitical power). However, her hands-on analysis of monetary conjunctures also gave rise to profound reflections on the ways in which capitalism generates very particular relationships to space and time. It is by looking at this spatio-temporal dimension of de Brunhoff's concepts that this paper aims to reveal the novelty, power and fruitfulness of her monetary analysis. Before further examining these concepts, however, it seems necessary to clarify Suzanne de Brunhoff's general approach to the monetary fact in capitalism. This essay is therefore divided into two parts: the first one will seek to define the meaning of the notion of general equivalent that she extracts from her reading of Karl Marx's Capital, before situating her approach in relation to 
Institutionalist approaches of money. The second part will then turn to de Brunhoff's analysis of the particular time-spaces of capitalism, and will successively address the following issues: (1) how de Brunhoff seizes the Keynesian idea of money as a bridge between present and future in order to reveal the way in which uncertainty about the future becomes a constitutive challenge of class policy, that is, how time itself becomes a class relationship; (2) how space, prior to being a field of expansion of capital or a concrete fact of imperialism, refers to a set of relations which are internal to the institutions of capital, thus showing that the question of space does not primarily refer to the distant action of the State on the circulating objects of capital (currency and labor power), but rather to the conditions of formation of the State as Subject; (3) how the credit system turns capitalism into a system that is never contemporary with itself, each social formation being defined by its relational mode with post-capitalist and pre-capitalist elements within the dynamics of its capitalist present. This leads to a new conception of the notion of unequal and combined development.

\section{BRUNHOFF'S CREATIVE ORTHODXY AGAINST MONETARY}

\section{HETERODOXY}

\section{The general equivalent and the unity of Capital}

One of the most striking aspects of Marx on Money, as well as Suzanne de Brunhoff's other books, is their discrepancy from other well-known readings of the first section of Capital: whether Engels' understanding of it as the historical reconstruction of the simple market mode of production, or the Neue Marx Lektüre interpretation, which makes it the theoretical exposition of the value-form (Elbe, 2013). While most approaches to money in Marx seem to be based on a cursive reading of this section, and Althusser famously recommended to skip it when reading Capital for the first time, de Brunhoff writes: "All who want to understand the whole contribution of Marx's historical materialism should read the first section, of Volume 1 of Capital, where a theory of commodities and money is presented" (1976a, p. 125). Yet, Marx on money does not offer a general reconstruction of Capital based on this initial premise; and neither does de Brunhoff use this section as the raw material for a social theory of alienation or reification by money. It could not even be 
argued that de Brunhoff seeks to update or to adapt Capital to more recent monetary and financial phenomena, i.e. to sort out these elements of the book that the movement of history has left behind from those that still remain actual. Her approach is more modest in appearance, yet its theoretical effects are far-reaching: above all, de Brunhoff seeks to demonstrate the crucial importance of the notion of general equivalent, and the particular nature of the monetary form within Marxist commodity theory (1976a, p. xiv).

The strength of Suzanne de Brunhoff's analysis stems from her ability to demonstrate that, without its prior genesis in the first section of Capital, the notion of general equivalent could not have been elaborated. If failing to consider it, she suggests, we would not be able to grasp the crucial importance of the general equivalent for the entire economy of capital, and would also lack the means of understanding how it continues to operate in forms of financial circulation that are removed from monetary circulation itself. The notion of general equivalent has two different meanings, whether considered from a theoretical or practical perspective. General equivalent means of course that money represents the value of all commodities and that, conversely, all commodities relate to each other through their relationship to money. But above all, general equivalent also means that all commodities must be exchanged for money in order to validate their existence as commodities, i.e. their existence as a social use value (Marx, 1867, p. 201). In other words, the notion of general equivalent refers both to the general representative of all values and to the monetary constraint weighing on the exchange of values, a constraint that is specific to any market economy and irreducible to the capitalist mode of production, continuing to impose itself as such in the most developed forms of monetary circulation. It is this dual aspect of monetary constraint - as both specific to the capitalist economy as a market economy and distinct from the capitalist economy as properly capitalist - that explains the particular status of the first section: it is both separate from and absolutely essential to understanding the rest of the work, justifying and overshadowing all the subsequent sections of Capital. 
Despite the fact that Suzanne de Brunhoff traces the genesis of the general equivalent without referring to any particular mode of production, she nevertheless draws from her analysis of commodity and money a decisive insight on the social structure corresponding to this genesis. Regardless of the mode of production in which money is used as a general equivalent, the economic sanction of the market reflects the fact that commodities and money are not socially neutral. The relationship that underlies social existence and determines the role of money is therefore "a sign of an essential division of society, on which the economic power of money rests" (1976a, p. 47). The general equivalent is both an economic phenomenon and a social relationship, and these two aspects must always be properly measured in the analysis of the various monetary and financial practices of capitalism.

\section{The universal equivalent versus the universality of the equivalent}

In contrast to her approach, Institutionalist understandings of money are typically based on the "elimination of Marxist notions of value and general equivalent and the highlighting of equivalence relations as the basis of market exchanges" (1979, p. 9). Such elimination inverts the relationship between wealth and money. While using money as a starting point, Institutionalism seeks to determine how money produces a space of equivalence for the wealth exchanged on the market (Aglietta and Cartelier, 1998, p. 133). According de Brunhoff, while no market society can indeed exist without money (Mollo, 2018, p. 95), money should not be seen as something that precedes the existence of market society. Defining money as a general equivalent requires starting from commodities in order to determine how the exchange of wealth produces an equivalent of its value that determines the specific monetary nature of money. It is only through this process that a market constraint gets imposed on the capitalist economy, regardless of the nature of the monetary regime (commodity or fiat money) (Brunhoff, 1979, p. 10).

Like Institutionalists, Suzanne de Brunhoff views money as a social relationship, as the ultimate expression of the social order of the market (Bellofiore, 2018). But a social relationship based on money cannot be universal as claimed by Modern Money Theory (Ingham, 2000). Money is 
undoubtedly everywhere, and has always been. The existence of a monetary social order, however, requires that money be exchanged for all the products of social labor, or rather, for the social labor power. It is on this condition, and this condition only that money achieves the socialization of individuals in the market order. This helps explain why de Brunhoff's incursions into monetary history are not directly concerned with the accumulation of capital; or her argument that the labor or valorization process only becomes of interest if "the analysis of money is part of that of the conditions of capital formation and functioning" (de Brunhoff, 1979, p. 10). De Brunhoff does not seek to universalize monetary forms and functions based on existing monetary structures. On the contrary, her goal is to shed light on the monetary system specific to the capitalist organization of exchanges through the motley history of monetary practices.

As a matter of fact, the universalization of the monetary fact separates money from the world of commodities in two ways: on the one hand, it posits money as an institution prior to any exchange of commodities; on the other, it reduces it to its supposed generic functions of measuring and settling debts, thus standing it against a debt system (Innes, 1914). Hence confidence, as the sole guarantor of the value of money and the validity of the monetary system. Thus, monetary crises are always crises of confidence, which manifest themselves in the search for "an anchor outside the financial system" (Aglietta and Cartelier, 1998, p. 143) (precious metals, foreign currency, substitute commodities). However, it is precisely these crises of confidence that reveal the specific nature of money in market societies, which distinguishes it entirely from all other forms of settlement. It is during these crises that the generic functions of money as a unit of account and a means of payment rely on its role as a general equivalent, even when the crisis displaces it onto a foreign currency or precious metals. For Suzanne de Brunhoff, then, what needs to be explained "is the economic basis for the existence of money, not merely as a measure of value and a means of circulation, but as the object of a specific demand even when its predominant form is inconvertible paper" (Brunhoff, 1976a, p. xv). By generalizing the debt economy of the capitalist credit system across the course of history, Institutionalism abolishes the difference between money and credit 
(Wray, 1998), thus ignoring the market constraint posed by money as a general equivalent within the credit system itself.

\section{THE TIME-SPACES OF CAPITALISM}

\section{Money and time as class policy}

From her Marxist standpoint, Suzanne de Brunhoff is not troubled by the end of the gold standard and subsequent transition to the regime of unconvertible fiat money, which she does not see as contradictory with Marx's theory of money. Indeed, instead of wondering whether and how the theory of commodity money remains valid under this regime or whether the law of value still applies in the absence of any market base for money, de Brunhoff asks: how does the general equivalent reproduce itself when credit money and base money coexist, and base money itself is no longer convertible into gold? In other words, how does monetary constraint operate in a credit system that consists of book entries, notes issuance, and ex nihilo deposits creation that seem to depend on the sole goodwill of banks? (Brunhoff, 1971, p. 10)

Suzanne de Brunhoff does not deny the fact that, within the monetary system, the issuance of unconvertible central money can lead to an excess of money supply and therefore to inflation (Aglietta, 1977, p. 654). Unlike monetarism, however, she does not understand inflation as a result of bad monetary policy. Rather, she sees it as the expression of a realization crisis affecting capitalist production relationships which monetary policy can hardly control. "Inflation is a form of realization crisis when the social validation of private work is carried out with the mediation of the State issuing non-convertible notes" (1976c, p. 39). As a product of the forced conversion of private bank money into central bank money, inflation makes it possible to spread the crisis of overaccumulation through the pseudo-social validation of production (Brunhoff and Cartelier, 1974), instead of letting it end abruptly as used to be the case at the time of the gold standard. It makes it possible to transfer to all money users (and in particular to wage earners, as monetarism demonstrates a contrario by denouncing the cumulative effects of price and wage increases 
following an excess supply of money) the risk of the non-realization of commodities and the devaluation of credits.

While this crisis escapes the immediate control of the bourgeoisie, its particular form, however, is not the result of a misguided monetary policy, but of a deliberate class policy. Even if not desired, inflation is always the effect of a monetary policy geared towards a specific goal, namely: to free the capitalist present from the past and the future. Antonio Negri has convincingly demonstrated this point in his analysis of John Maynard Keynes' thought (Negri, 1988, p. 13). Monetary policy must not only contribute to increasing the marginal efficiency of capital; above all, it must also release the bourgeoisie from the anguish of a risky future. Thanks to the convertibility of private monies into central money, the monetary authorities reduce the burden of the past by guaranteeing the value of investments, while simultaneously removing a part of uncertainty through the social validation of future production (1976c, p. 39) ${ }^{2}$.

But Suzanne de Brunhoff emphasizes an important element that Keynes refused to consider. As in a system of communicating vessels, at the same time as it diminishes uncertainty for the bourgeoisie through its money management, the State increases it for the proletariat through its labor power management: by establishing a division between employees receiving indirect wages and hourly employees, between permanent contracts and fixed-term contracts, between stable and precarious jobs, etc. As de Brunhoff writes: "This is why assistance to the poor at the beginning of the 19th century, this archaism, is still today a living form that runs through the most modern institutions of Social Security, especially in the United States. The modifications of capitalist accumulation, as well as of the class struggle, transform the conditions of state management of the labor power, but there are always elements of different ages" (1976c, p. 8). Here again, in addition to introducing class relations into her analysis of the management of money, de Brunhoff introduces the element

\footnotetext{
${ }^{2}$ The risk is then transformed into a devalorization of the national currency, which moves the constraint imposed by the law of value to the exchange rates between the different unconvertible monies and raises the issue of the dollar as a universal equivalent while gold standard is away.
} 
of time into her understanding of class relations. In other words, by viewing the differential relationship to time as the expression of a class relationship, this relationship to time becomes a political variable. From that perspective, inflation can be viewed as the return in the capitalist present of both the burdens of the past and the uncertainties of the future, hence the need for a new class strategy that will have a direct impact on the workers' present. Thus, a few years after the first oil crisis, de Brunhoff explains in her afterword to the third edition of Marx on money: "That the bourgeoisie today seeks to manage the crisis by a frontal attack on the level of wages and employment shows us that capitalist money and credit can be not the instruments of economic control, but the auxiliaries of a class policy" (1976b, p. 204).

\section{Distance action and State ideology}

In a credit system based on a regime of unconvertible money and consisting of deposit-taking banks and a central money-issuing bank, what is known as monetary policy refers primarily to a centralized method of determining the various forms of money circulating in a given monetary area. This is due to the fact that, taken separately, each type of money (scriptural and central) equals less money than the other: on the one hand, scriptural money can only form a whole if it is guaranteed by the existence of central money; on the other, central money does not fully circulate as a means of payment among the public. In other words, neither form of money is the 'base money' of the other and only their regulated combination can guarantee the functioning of credit money as a general equivalent.

In addition, these two types of money are constantly differentiated by their mode of issuance and their respective uses, hence the permanent problem of their relationship, which threatens the role of money as a general equivalent and therefore requires what is called a monetary policy adjustment of the money supply (1971, p. 126). As Suzanne de Brunhoff warns, however, this is a misleading expression, since money issuance always originates from the demand for money to second-tier banks. The central bank can only react to this demand, whether in a pro-cyclical or counter-cyclical way, in an accommodating or restrictive way, but always according to a given situation that it can 
certainly influence but never determine nor control (1973, pp. 65-66). Yet, since the central bank stands at the top of the monetary system, the "conflicting centralization" (1986, p. 104) relationship between private banks and the central bank is wrongly presented as a monetary policy. Thus, concerning the management of money, there is always a 'monetary policy' as an ideology directly resulting from the central bank's position in the monetary space of capitalism. For de Brunhoff, this State ideology is first and foremost a question of distance, of a distance relationship between the individuals, classes and State institutions that are involved in economic and social life.

Let us consider the State action during the Fordist era, which began around the 1930s. From that moment, the State was based on its two main pillars of societal intervention: monetary policy on the one hand, and employment and wage policies on the other. And what gave State action its formal unity was a profound change in the way the State related to labor, a change whose novelty and specificity necessarily escaped the conception of the State as a power over life, as a biopower (Foucault, 2008). The nature of this change in the relationship between the State and capitalist society is that labor power was now viewed as a single wage bill, as a large flow of monetary income. This is indeed what the Keynesian revolution was all about: the inclusion of the working class as an economic subject in a circuit flow representing the formation and allocation of monetary income under State control. In other words, Keynes's contribution to economic thought was the evacuation and substitution of labor value for objects of determined behavior only expressed in monetary flows. But as Suzanne de Brunhoff insists, at the level of State practice, economic policy operates simultaneously on two fronts, namely money and labor power: with the development of capitalism, she notes, these two elements "must be treated as homogeneous flows, sliding into each other" (1976c, p. 5). Indeed, "[t]he ability of money to function as a means of payment now depends primarily on the transformation of bank credits into wage payments, which in turn are spent on consumer goods; and wages as 'strategic' income are fuelled by bank financing” (1976c, p. 5). The function of the State is precisely to unify the diversity of these flows and to give them a political coherence. If one presupposes the unity of the State, manipulating and adjusting these 
flows, "one misses the effective movement that takes place as unification and political anchoring of diverse elements" (1976c, p. 71). Thus, in order to grasp the effective movement of this unification, any theory of the modern State must begin with State interventions (economic policy) in order to infer the resulting form of the political State at any given stage of capitalism.

The aim of Suzanne de Brunhoff's The State, Capital and economic Policy is thus to examine the way in which the State operates in relation to the capitalist circuit, from which it necessarily remains external. We have seen that State intervention in money consists in ensuring the maintenance of the quality of the means of payment whose issuance is beyond the control of the central bank; and how its role is circumscribed by the development of private credit relations and financial circulation. We must therefore consider money management as both immanent and external to the relations of capitalist circulation. More fundamentally, money and labor power management by the State demonstrates that, far from suppressing it, the immanence of the State implies an exteriority in relation to the movement of capital that articulates the elements of the 'MC-M' circuit between them. This is what leads de Brunhoff to argue that the State not only functions "with violence" and "with ideology", but also "with distance" (1976c, p. 88). And it is precisely this distance, required by capitalist production itself, which makes it appear as a socially neutral Subject carrying rules applicable to all (1973, p. 191). Rather than as an ideological apparatus, then, the State is itself defined as an ideological construct, one that arises from its particular position within a particular social topos. From that perspective, the State is less concerned with individuals as subjects, than with presenting itself to these individuals as a third body capable of mastering money and labor power management under the name of economic policy.

\section{The non-contemporaneity of capitalism with itself}

According to Suzanne de Brunhoff, monetary policy and, more generally, economic policy is both an action at a distance on capital and an action on the temporality of capitalism. But monetary policy, as a late product of the credit system on which it acts, is also a balancing act between the before and after of capitalism, that is, between post-capitalism and ante-capitalism. This is due to 
the dual nature of the credit system, which is composed of both financial products that push capitalism beyond itself, and of a monetary base that predates the emergence of capitalism and continues to act as a constraint on the current capitalist system.

The crises of modern capitalism are typically described as monetary or financial crises, because the credit system is always both ahead and behind the dynamics of capital, never coinciding with the capitalist present. "The world would still be without railways if it had had to wait until accumulation had got a few individual capitals far enough to be adequate for the construction of a railway. Centralization, however, accomplished this in the twinkling of an eye, by means of jointstock companies" (Marx, 1867, p. 780). But while the credit system creates the necessary conditions for accelerating the development of production and exchanges beyond its current possibilities, it always remains dependent on a monetary base inherited from commodity production, one that precedes capitalism and makes it a heterogeneous system. The credit system is both post-capitalist - through its sophisticated credit instruments and financial assets - and antecapitalist - because financial securities must be able to be converted into money at any given time. In short, the credit system is never truly contemporary with capitalism; it is constantly torn between its tendency to bypass the constraints of the capitalist present (through credit itself), and the need to convert all these securities into sound and stumbling cash, which becomes brutally manifest in times of crisis. Despite being adapted to the needs of capitalism, the financing system that was born out of capitalist circulation remains a bastard financing system, the "monetary base" of which "becomes apparent whenever it is at risk of going out of service, whether in domestic or international financial circuits" (1979, p. 147). Insofar as this system is inherent to the capitalist mode of production, we can go further by generalizing this combination of relic and novelty to all dimensions of capitalism.

Marx has repeatedly pointed out how the respective levels of economic development of different countries entail the coexistence of archaic and modern forms of the bourgeoisie and State apparatus. Thus, in the midst of the Industrial Revolution, the German bourgeoisie was busy with processes of 
industrialization that the French and British had accomplished during the age of mercantilism. Likewise, at a time when England had a cheap State that was adapted to the needs of industrial development, France was developing an expensive State apparatus as a result of the hold of the Banks and Stock Exchange on the country (1976c, p. 100). But Suzanne de Brunhoff is most interested in those cases when Marx demonstrates the presence of anachronistic aspects in the making of the present, such as when in order to accomplish its revolution, the French bourgeoisie had to borrow elements from the Roman Empire that made it the bearer of universal interests. As de Brunhoff points out, however, this kind of process "is not an ideological deception, it is a necessity for the establishment of bourgeois hegemony" (1976c, pp. 100-101). More specifically, these observations lead her to draw lessons on class relations, as well as on the articulation of space and time in capitalist social formations.

Far from being a hallmark of the financial system, this combination of old and new is to be found at each stage of capitalism, in various forms and to varying degrees. No matter the period considered, there always exists a combination of relatively disparate elements, i.e. elements of different origins and ages that make it very difficult to identify and define the stages of capitalism: "the periods illustrated in terms of the monetary practices of the State do not directly reflect those which traditionally make it possible to define stages of capitalism, because of the division linked to the concept of the general equivalent, and the transformations of practices which correspond to the reproduction of this equivalent" (1976c, p. 102). We therefore cannot apply the same mode of temporal division when dealing with money and monetary practices, or labor and the composition of labor power.

Like money management, labor power management involves the coexistence of old and new elements. Assistance to the poor, for example, coexists with a system of employer and employee contributions, and "this kind of anachronism is not accidental. It has indeed a class function, namely: the division of the proletariat according to the coexistence of different forms of management at any given moment, while also taking into account the need of maintaining 
insecurity for the whole" (1976c, p. 8). For example, the reduction of unemployment benefits or the difficulties for accessing them cannot be understood without considering the transformation of the role of unemployment in the relationship between employment and consumption: during the Fordist era, for example, the maintenance of the unemployed, insofar as it gave rise to a demand for consumption goods, was essential to maintaining the level of employment and therefore the level of wages of the labor power being employed. Conversely, the security of the unemployed depended on the retention of contributing employees. Thus, the fragmentation of the labor power was both the condition and the result of the complementarity of the various components of this labor power.

This composite character of capitalism, this non-contemporaneity of capitalism with itself that Suzanne de Brunhoff first identifies in monetary practices and later extends to all relations internal to capitalism, contributes to the renewal of the notion of unequal and combined development by introducing the notion of time - whereas Rosa Luxemburg ([1913] 2003) and Leon Trotsky (19321933 2008) only conceived the relationship between capitalism and non-capitalist formations in terms of space. Undoubtedly, the law of combined development depends on unequal rhythms of social formations development, but it subordinates this inequality to the combination of archaic and modern spaces, i.e. it subordinates time to space. For de Brunhoff, in contrast, the heterogeneity of capitalism gives rise to a truly relativistic conception of capitalist space-time. Much has been written on the relationship of Capital with Newtonian physics and the laws of thermodynamics, often relegating Marxism to a science of the past. But if classical physics helps understanding the ways in which capital produces, another paradigm is needed in order to grasp how capital reproduces itself by expanding its field of valorization. Another time-space is required here, as each social formation must be understood as a system of differential relationships of spatial and temporal elements, as a distinctive formal arrangement of space and time. Not unlike in the theory of relativity, where space-time is determined by phenomena (rather than conditioning their appearance), each social formation of capitalism determines a particular space-time, instead of being conditioned by a uniform global space and linear time. Thus, each period in the history of 
capitalism constitutes a distinctive block of space-time. Moreover, each economic space within a period forms a separate block of space-time. For example, let us ask the question: why is England the only nation that seems to have developed entirely in a capitalist mode, whether in the countryside or in the city? As de Brunhoff explains, this is due to the fact that, as a result of its international commercial and colonial domination over pre-capitalist formations that were forced to become contemporary with capitalism which they "preceded" (1976c, 101), it was able to homogenize the relations of capitalist production within its internal borders. "If the 'modern' needs the 'old', it is because the context of capital is not entirely capitalist, nor can it be, even tangentially" (1976c, p. 101). Thus, England substituted the unequal and combined space of its empire with the heterogeneous time of its national space, in which archaisms and novelties coexisted "as resurgences of the past in the capitalist present" (1976c, p. 101). But English capitalism still remained a multiple-time system, that is, a system whose social field is never entirely contemporary with itself.

\section{CONCLUSION}

By grounding her analysis on monetary and financial practices, Suzanne de Brunhoff renews Marxist approaches to money, credit and the State. However, it is by it preserving the Marxist notion of a market constraint imposed by money, which remains actual even in a fiduciary money regime, that she distances herself from both monetary orthodoxy (Quantity Theory) and Institutionalist or post-Keynesian theories.

As we have seen, Suzanne de Brunhoff's use of the concept of pseudo-validation helps understanding the role of monetary policy as a means of managing time, of freeing capital from the weight of the past and the uncertainty of the future to the detriment of labor. Whereas Marxism has insisted on the weight of the past in the dynamics of accumulation and crises (the preservation of existing value, the increase in the organic composition of capital), de Brunhoff follows Keynes by putting the emphasis on the uncertainty of the future. But while Keynes saw this control of the 
future as a means of containing the financial bourgeoisie, she primarily understands it as an attack of the bourgeoisie as a whole against the living conditions of the proletariat.

In the same way as her analysis of monetary policy reveals how the management of time is becomes the real object of a class policy, her analysis of State intervention also demonstrates that the ideological place and role of the state results from a dialectic of immanence and exteriority, one that turns state intervention into an art of distance action. This notion of distance, through which she approaches politics, expresses the special status of the State in capitalist social formations, which results from its functional role in the dynamics of capital prior to its directly repressive or ideological functions.

Next, by defining the credit system as a post-capitalist form of monetary relations, and therefore a source of permanent crisis for the capitalist present, Suzanne de Brunhoff's creative orthodoxy stands out from both Hilferding's credit-led organized capitalism ([1910] 1981) and Hyman Minsky's credit-led financial instability. Whereas the former relies on the merging of banking and industry for regulating global capitalism, the latter sees, on the contrary, the leveraging activity of the banks as the root cause of financial instability (Papadimitriou and Wray, 1999). As demonstrated by de Brunhoff's analysis of the credit system, the instability of capitalism stems from the very nature of the monetary relations on which capitalism in general is based. It is only in this sense that one could speak of a structuralism in de Brunhoff's thought: through her analysis of money and credit, she locates in the structure of capitalism both the spring of its historicity and the source of its permanent fragility.

More deeply and finally, we saw how, starting with her analysis of the credit system, Suzanne de Brunhoff identified in all capitalist social relations the presence of pre- and post-capitalist elements. By presenting capitalism as a social system that is never contemporary with itself, de Brunhoff lays the groundwork for a properly relativist approach to capitalist space-time. 


\section{REFERENCES}

Aglietta, M. 1977. “Brunhoff (S. de)—État et capital.” Revue économique 28 (4): 651-655.

Aglietta, Michel and Cartelier, Jean. 1998. “Ordre monétaire des économies de marché.” In Michel Aglietta and André Orléan, eds., La monnaie souveraine. Paris: Éditions Odile Jacob, pp. 129157.

Althusser, Louis. 2005. For Marx. London; New York: Verso.

Bellofiore, Riccardo. 2018. “Comment devenir marxien? L’héritage de Suzanne de Brunhoff.” In Riccardo Bellofiore, Daniel Cohen, Cédric Durand and André Orléan, ed., Penser la monnaie et la finance avec Marx: Autour de Suzanne de Brunhoff. Rennes: Presses universitaires de Rennes, pp. $31-42$.

Bourdieu, Pierre and Loïc J. D. Wacquant. 1994. An invitation to reflexive sociology. Chicago: University of Chicago Press.

Brunhoff, Suzanne de. 1971. L'offre de monnaie. Histoire d'un concept. Paris: Maspero.

Brunhoff, Suzanne de. 1973. La politique monétaire. Un essai d'interprétation marxiste. Paris: Presses Universitaires de France.

Brunhoff, Suzanne de. 1976a. Marx on money. Second edition. London: Verso.

Brunhoff, Suzanne de. 1976b. La monnaie chez Marx. Paris: Éditions sociales.

Brunhoff, Suzanne de. 1976c. État et capital: Recherches sur la politique économique. Grenoble: Presses universitaires de Grenoble.

Brunhoff, S. de. (1976d). Crise capitaliste et politique économique. In N. Poulantzas (Ed.), La crise de l'État. Paris: Presses Universitaires de France.

Brunhoff, Suzanne de. 1979. Les rapports d'argent. Grenoble: Presses universitaires de Grenoble.

Brunhoff, Suzanne de. 1986. L’heure du marché: Critique du libéralisme. Paris: Presses universitaires de France. 
Brunhoff, Suzanne de and Cartelier, Jean. 1974. "Une analyse marxiste de l'inflation," Chronique sociale de France, 4. In Brunhoff, Suzanne de. 1979. Les rapports d'argent. Paris : Presses universitaires de Grenoble/Maspéro.

Elbe, Ingo. 2013. "Between Marx, Marxism, and Marxisms - Ways of Reading Marx's Theory." Viewpoint Magazine. https://www.viewpointmag.com/2013/10/21/between-marxmarxism-and$\underline{\text { marxisms-ways-of-reading-marxs-theory/ }}$

Foucault, Michel. 2008. The birth of biopolitics: Lectures at the Collège de France, 1978-79. Basingstoke [England]; New York: Palgrave Macmillan.

Hilferding, Rudolf [1910] 1981. Finance capital: A study of the latest phase of capitalist development. London; Boston: Routledge and Kegan Paul.

Ingham, Goeffrey K. 2004. The nature of money. Cambridge, UK; Malden, MA: Polity.

Innes, Alfred Mitchell. 1914. "The credit theory of money.” In L. Randall Wray, Credit and State Theories of Money, pp. 50-78.

Luxemburg, Rosa. [1913] 2003. The accumulation of capital. London; New York: Routledge.

Marx, Karl. [1867] 1990. Capital: Volume one. London: Penguin Books.

Minsky, Hyman P. 1992. "The financial instability hypothesis." The Jerome Levy Economics Institute, WP N74. Available at Social Science Research Network website: https://papers.ssrn.com/abstract $=161024$

Mollo, Maria de Lourdes Rollemberg. 2018. "La monnaie comme rapport social dans la pensée hétérodoxe française.” In Riccardo Bellofiore, Daniel Cohen, Cédric Durand and André Orléan, eds., Penser la monnaie et la finance avec Marx: Autour de Suzanne de Brunhoff. Rennes: Presses universitaires de Rennes, pp. 75-103.

Moseley, Fred, ed. 2005a. Marx's theory of money. London: Palgrave Macmillan UK.

Moseley, Fred. 2005b. Marx's theory of money modern appraisals. Available at http://link.springer.com/book/10.1057/9780230523999 
Negri, Antonio. 1988. Revolution retrieved: Writings on Marx, Keynes, capitalist crisis, and new social subjects (1967-83). London: Red Notes.

Orléan, André. 2018. "De quelques débats à propos de la production marchande chez Marx.” In Riccardo Bellofiore, Daniel Cohen, Cédric Durand and André Orléan, eds., Penser la monnaie et la finance avec Marx: Autour de Suzanne de Brunhoff, Rennes: Presses universitaires de Rennes, pp. $45-74$.

Papadimitriou, Dimitri. B. and L. Randall Wray. 1999. "Minsky’s analysis of financial capitalism, The Jerome Levy Economics Institute, WP № 275. Available at

https://papers.ssrn.com/sol3/papers.cfm?abstract id=180071

Postone, Moishe. 1993. Time, labor, and social domination: A reinterpretation of Marx's critical theory. Cambridge: Cambridge University Press.

Reichelt, Helmut. 2007. "Marx's critique of economic categories: Reflections on the problem of validity in the dialectical method of presentation in capital." Historical Materialism 15 (4): 3-52.

Trotsky, Leon. [1932-1933] 2008. History of the Russian revolution. Chicago, IL: Haymarket Books.

Wray, L. Randall. 2010. "Money." Levy Economics Institute, WP N647. Available at: http://www.levyinstitute.org/pubs/wp_647.pdf

Wray, L. Randall. 1998. "Modern money." The Jerome Levy Economics Institute, WP N²52. Available at: https://papers.ssrn.com/abstract=137409 